\title{
ПРОБЛЕМЫ ИНДИВИДУАЛЬНОГО ДОЗИРОВАНИЯ ЛЕКАРСТВЕННЫХ ПРЕПАРАТОВ
}

\author{
С.Э. Кондаков ${ }^{1}$, В.В. Гордеев ${ }^{1,3}$, С.Н. Егорова ${ }^{2}$, Ю.А. Абдуллина ${ }^{2}$ \\ ${ }^{1}$ Химический факультет, ФГБОУ ВО «Московский государственный университет имени \\ М.В.Ломоносова», 119991, Россия, г. Москва, Ленинские горы, д. 1, к. 3. \\ ${ }^{2}$ Институт фармации, ФГБОУ ВО «Казанский государственный медицинский \\ университет» Минздрава России, 420012, Россия, г. Казань, ул. Бутлерова, д. 49. \\ ${ }^{3} 000$ “ФармПринт”, 115201, Россия, г. Москва, ул. Котляковская, д. 3, с. 13.
}

DOI: 10.19163/MedChemRussia2021-2021-196

E-mail:kse@excite.chem.msu.ru

Развитие персонализированной медицины, а также специфика фармакотерапии в педиатрии обусловливают необходимость индивидуального дозирования лекарственных препаратов (ЛП). В фармации для обеспечения персонализированной дозы ЛП промышленного производства используются дозирующие устройства: капельницы, мерные емкости - для жидких пероральных лекарственных форм, распылитель-дозатор - для аэрозолей и спреев резорбтивного действия; на таблетки наносятся разделительные риски. Однако промышленный выпуск унифицированных составов не позволяет обеспечить индивидуальное дозирование фармацевтических субстанций в большинстве видов лекарственных форм, не подлежащих разделению: таблеток, покрытых оболочкой (в том числе кишечнорастворимых и пролонгированного действия), матричных таблеток, капсул, суппозиториев и др. Медицинской, фармацевтической и экономической проблемой является отсутствие на фармацевтическом рынке детских лекарственных форм для парентерального применения уменьшенных объемов и/или концентраций. Проведенный нами анализ патентной информации показывает перспективность развития аптечного изготовления ЛП по индивидуальным прописям с использованием тритураций-полуфабрикатов фармацевтических субстанций ${ }^{1}$. Использование 2D- и 3D-печати ${ }^{2}$ позволяет обеспечить не только точность индивидуального дозирования, но и направленное высвобождение лекарственных веществ, сочетать их микроколичества в персонализированном ЛП.

Проблемами экстемпорального изготовления ЛП по индивидуальным прописям являются отсутствие в аптеках аналитического оборудования для контроля содержания фармацевтических субстанций, возможное взаимодействие лекарственных и вспомогательных веществ, опасность перекрестного загрязнения технологического оборудования и ЛП и малый срок годности лекарственных форм аптечного изготовления.

\section{Литература}

1. С.Н.Егорова, А.Р.Хаятов, патент RU2659206. 2017, Бюллетень №19.

2. С.Э.Кондаков, В.В.Гордеев и др., патент RU 2674692. 2018, Бюллетень №35.

$$
-196-
$$

